\title{
CHARACTERISTICS OF STEEL PLATE-REINFORCED CONCRETE COMPOSITE BEAMS SUBJECTED TO FLEXURAL STRESSES
}

\author{
Yasser R. Tawfic ${ }^{1}$, Abdel-Nasser A. Soltan ${ }^{2}$, Amr B. Saddek ${ }^{3,4}$ \\ ${ }^{1}$ Civil Engineering Department, Minia University, Egypt \\ ${ }^{2}$ Civil Engineering Department, Minia University, Egypt \\ ${ }^{3}$ Civil Engineering Department, Beni-Suef University, Egypt \\ ${ }^{4}$ Civil Engineering Department, Al Baha University, Saudi Arabia \\ *Corresponding Author E-mail: yasser.rifat@mu.edu.eg
}

\begin{abstract}
Composite elements are generally used for special types of structures owing to their high efficiency. This research presents an experimental and theoretical investigation on the flexural behavior of low steel reinforcement ratio steel plate-reinforced concrete composite beams. The experimental program consists of 14 reinforced concrete specimens. Meanwhile, the theoretical study involves the verification of the experimental work and a parametric study on the behavior of the steel plate-reinforced concrete composite beams using nonlinear finite element software (ANSYS 18.1). The theoretical and experimental variables include the shape and thickness of the steel plates, the concrete compressive strength, the number of shear connectors, and the use of epoxy resin. The experimental test results revealed that the use of mild steel plates as a replacement for high-tensile steel reinforcements inversely affects the load-bearing capacity of the steel plate-reinforced concrete composite beams. However, when high-tensile steel plates were used as additional reinforcements, the nonlinear finite element analysis predicted up to a $40 \%$ increase in the values of the ultimate loads for the composite beams.
\end{abstract}

Key Words: Reinforcement ratio, Flexural strength, Composite, Steel plate, Shear connectors, Epoxy resin.

\section{INTRODUCTION}

There are different types of composite beams such as concrete slabs attached to steel sections [1-5], steel sections embedded inside concrete beams or steel plates attached to the outer surface of the concrete beams [68]. However, the use of steel sections significantly increases the steel reinforcement ratio, and these sections are inefficient, unless they are strongly fixed to the concrete sections.

The steel - concrete connection is an important aspect that influences the overall structural behavior of the composite section. The connection is substantial to make steel and concrete sections act as a single composite unit and to induce composite action. The shear connectors are used to establish the connection between steel and concrete [1]. The strength of the shear connection is generally determined by the arrangement and strength of the shear connectors in steel-concrete composite beams. In addition, it affects the structural behavior and failure mode of the composite beam. As a result, the design of steelconcrete composite beams requires specific attention to the degree of shear connection and the fatigue life of the composite beams increases with the increase in shear connection degree [2].

Laith Khaled et al. [6] conducted experimental and theoretical studies to evaluate the flexural behavior of steel channel-reinforced concrete composite beams. Despite the improvements of the ultimate load capacity, Received: 11Novamber, 2020, Accepted: 19 January , 2021
Laith Khaled et al concluded that a serious drawback to the use of this type of composite beam is the reduction of its ductility due to the introduction of the integrated steel channels. A reduction of the steel ratio reduces the risk of concrete crushing and increases ductility. The use of adequate number of shear connectors is found to be vital for reaching the full efficiency of the steelconcrete composite beams [9-14]. Stefan-Marius [9] indicated that a partial interaction phenomenon is exhibited in spite of the level of shear connection; therefore, a relative slip between the steel and concrete components will occur even in the case of a full shear connection. However, the increase in the number of shear connectors (over 100\% degrees of shear connection) will not induce a significant increase in the strength capacity or in the stiffness of the composite beams.

Conversely, a partial shear connection leads to a pronounced decrease in stiffness and ultimate load capacity. R. Mark Lawson et al. [10] reported that the use of steel-concrete composite beams with low degrees of shear connection between the beam and slab cause significant additional deflections due to slip in the shear connectors. Nasser H. Tu'ma et al. [15] conducted tests on 11 hollow composite beams fabricated using a hollow steel box. Their experimental variables included the steel box shapes, the cross-sectional area, and the location of the steel box. Their test results revealed that the composite hollow beams had a greater load and 
moment capacity than the non-composite beams (the ultimate load capacity increased significantly by 109\%). Although the presence of a hollow core in the concrete section reduced its moment of inertia, the use of a hollow steel box increased the capacity of the composite beams to resist deflections. El Basha et al. [16] presented the results of the experimental and analytical programs that they conducted to evaluate the flexural behavior of hollow Concrete-Encased Steel Tube (CEST) composite beams subjected to flexural stresses. The hollow CEST composite beams had larger elastic deformation, higher strength, and ductility compared with conventional reinforced concrete specimens.

The main objective of this research was to evaluate the flexural behavior of steel plate-reinforced concrete composite beams that have low steel reinforcement ratios. Steel plates with different shapes and thicknesses were fixed to the outside surface of the reinforced concrete beams as a replacement for steel reinforcement using either shear studs or shear anchors and epoxy resin.

\section{EXPERIMENTAL PROGRAM}

Table (1): Test Specimens
Table (1) presents the details of our experimental program consisting of two groups with a total of 14 reinforced concrete test specimens. These specimens have a rectangular cross section of $120 \times 300 \mathrm{~mm}$ and clear spans equal to $1600 \mathrm{~mm}$. Two beams served as control beams with three steel bars (diameter $12 \mathrm{~mm}$ ) as tensile reinforcement and two steel bars (diameter 12 $\mathrm{mm}$ ) as compressive reinforcement. Steel plates with different shapes and thicknesses were used as replacements for the steel reinforcements for the remaining 12 composite beams. The steel plates were fixed to the external surface of the reinforced concrete beams using shear connectors and epoxy resin. The experimental variables include the concrete strength (30 and $40 \mathrm{MPa}$ ), the shape (four different shapes) and thickness of the steel plates ( 1 and $1.5 \mathrm{~mm})$, the number of the shear connectors, and the use of epoxy resin. All specimens were simply supported and subjected to twopoint static loading until failure. Figure (1) shows the concrete dimensions and details of the reinforcements for the test specimens.

\begin{tabular}{|c|c|c|c|c|c|c|c|c|c|c|c|c|}
\hline \multirow{2}{*}{ Group } & \multirow{2}{*}{ Specimen } & \multirow{2}{*}{ Steel plate } & \multirow{2}{*}{$\begin{array}{l}\text { Thicknes } \\
\text { s of steel } \\
\text { pl. (mm) }\end{array}$} & \multicolumn{2}{|c|}{ Tensile bars } & \multicolumn{2}{|c|}{ Tensile steel pl. } & \multicolumn{2}{|c|}{$\begin{array}{l}\text { Total tensile } \\
\text { reinforcement }\end{array}$} & \multirow{2}{*}{$\begin{array}{c}\text { Total area of } \\
\text { compressive } \\
\text { reinforcement } \\
\left(\mathrm{mm}^{2}\right)\end{array}$} & \multirow{2}{*}{$\begin{array}{l}\text { Epoxy } \\
\text { resin }\end{array}$} & \multirow{2}{*}{$\begin{array}{c}\text { No. of } \\
\text { shear } \\
\text { connector } \\
\text { s }\end{array}$} \\
\hline & & & & $\begin{array}{c}\text { Area } \\
\left(\mathrm{mm}^{2}\right)\end{array}$ & $\mathrm{U}_{\mathrm{s} . \mathrm{b}}$ & $\begin{array}{c}\text { Area } \\
\left(\mathrm{mm}^{2}\right)\end{array}$ & Us.P. & $\begin{array}{c}\text { Area } \\
\left(\mathrm{mm}^{2}\right)\end{array}$ & $\mathrm{U}_{\text {total }}$ & & & \\
\hline \multirow{8}{*}{ I } & A1 & - & - & 339 & 1.05 & - & 0 & 339 & 1.05 & 226 & - & - \\
\hline & A2 & Steel plate & 1.0 & 226 & 0.70 & 120 & 0.37 & 346 & 1.07 & 226 & Epoxy & 5 \\
\hline & A3 & Steel plate & 1.0 & 226 & 0.70 & 120 & 0.37 & 346 & 1.07 & 226 & - & 8 \\
\hline & A4 & Steel plate & 1.0 & 226 & 0.70 & 120 & 0.37 & 346 & 1.07 & 226 & - & 5 \\
\hline & A5 & U-shape & 1.0 & 157 & 0.49 & 270 & 0.83 & 427 & 1.32 & 226 & - & 8 \\
\hline & A6 & U-shape & 1.5 & 157 & 0.49 & 405 & 1.25 & 562 & 1.74 & 226 & - & 5 \\
\hline & A7 & Open Box 1 & 1.0 & 157 & 0.49 & 270 & 0.83 & 427 & 1.32 & 257 & - & 8 \\
\hline & A8 & Open Box 2 & 1.0 & 157 & 0.49 & 270 & 0.83 & 427 & 1.32 & 257 & - & 8 \\
\hline \multirow{6}{*}{ II } & B1 & - & - & 339 & 1.05 & - & 0 & 339 & 1.05 & 226 & - & - \\
\hline & B2 & Steel plate & 1.0 & 226 & 0.70 & 120 & 0.37 & 346 & 1.07 & 226 & - & 8 \\
\hline & B3 & Steel plate & 1.0 & 226 & 0.70 & 120 & 0.37 & 346 & 1.07 & 226 & - & 5 \\
\hline & B4 & U-shape & 1.0 & 157 & 0.49 & 270 & 0.83 & 427 & 1.32 & 226 & - & 8 \\
\hline & B5 & U-shape & 1.5 & 157 & 0.49 & 405 & 1.25 & 562 & 1.74 & 226 & - & 5 \\
\hline & B6 & Open Box 1 & 1.0 & 157 & 0.49 & 270 & 0.83 & 427 & 1.32 & 257 & - & 8 \\
\hline
\end{tabular}



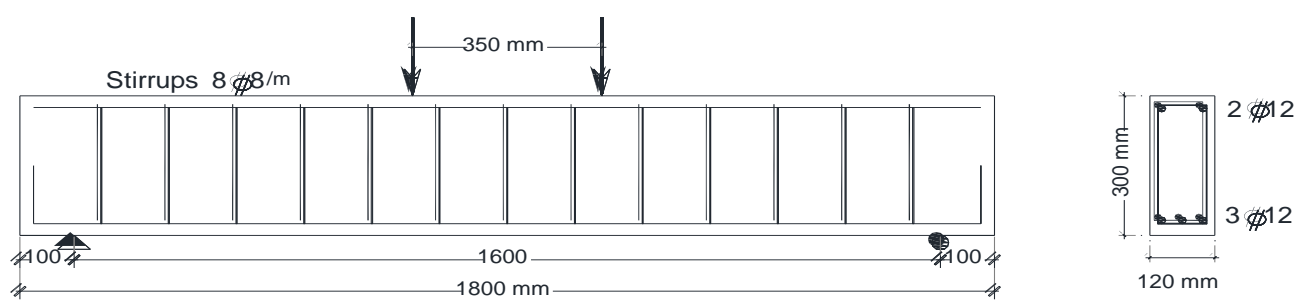

Control Beams A1,B1
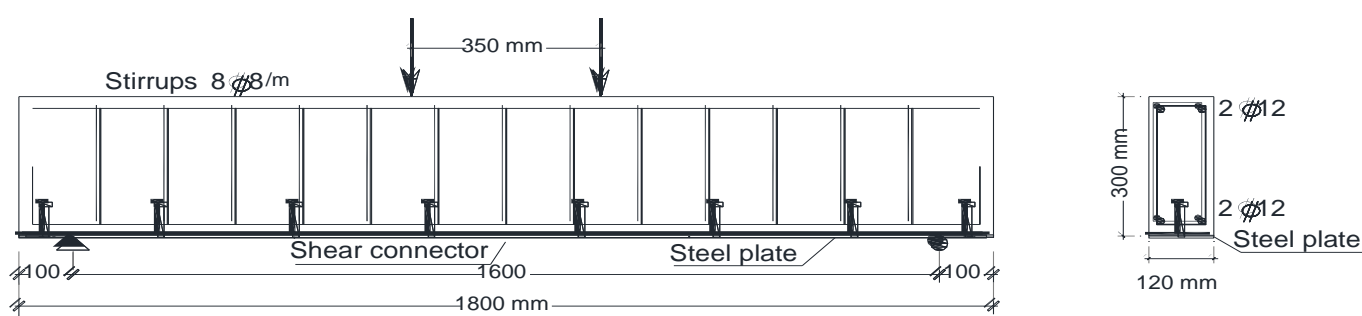

Beams A3, A4,B2 and B3 (5 or 8 studs).
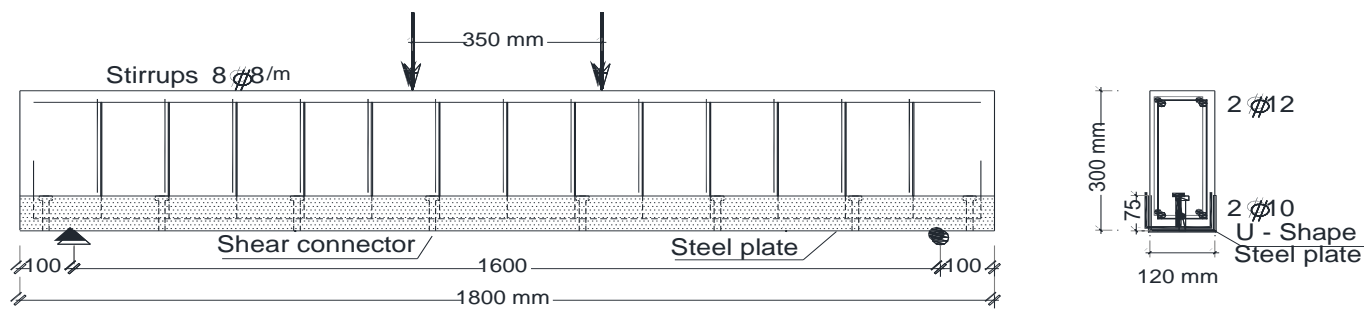

Beams A5, A6, B4 and B5 (5 or 8 studs).
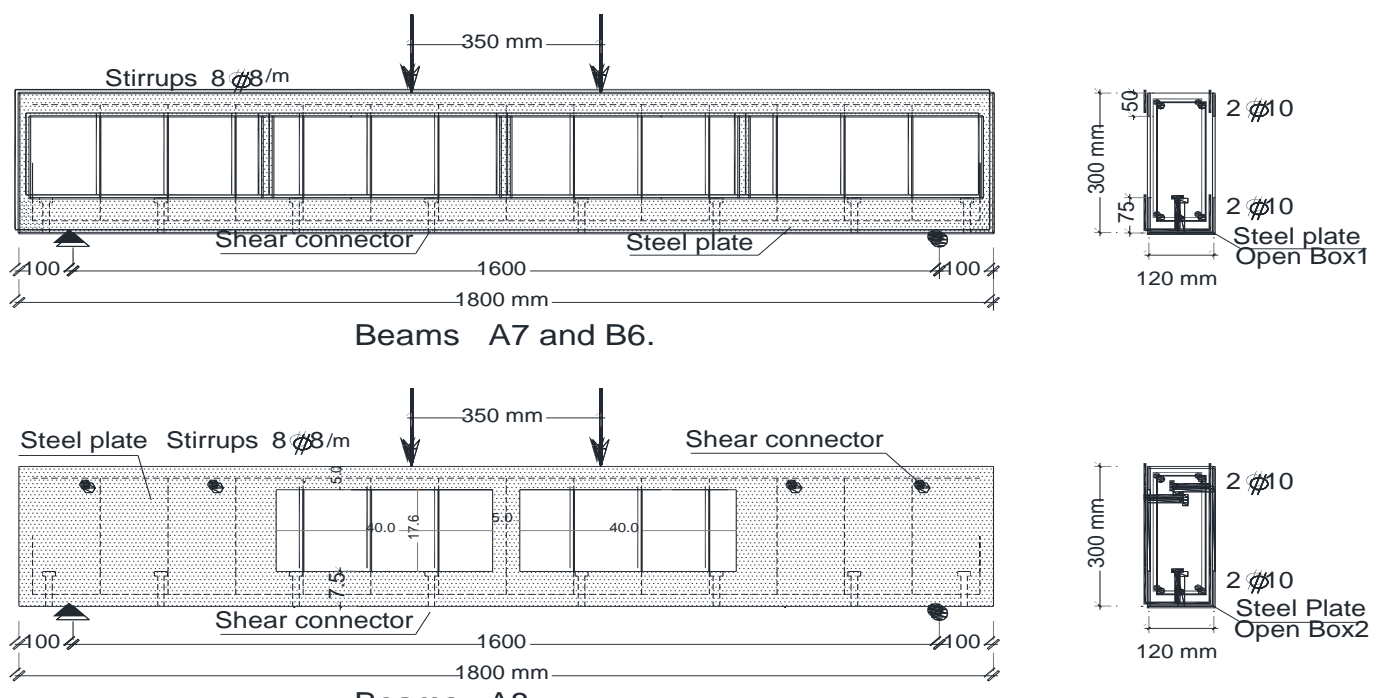

Figure (1): Concrete dimensions and details of reinforcement of the test specimens.

\subsection{Material properties}

\subsubsection{Cement}

Ordinary Portland cement was used to cast all of the test specimens. The surface area of the cement was 3250 $\mathrm{cm}^{2} \mathrm{gm}^{-1}$, and the specific gravity and 28-day compressive strength of the cement were 3.15 and 48 $\mathrm{MPa}$, respectively.

\subsubsection{Fine and coarse aggregate}

Natural sand and gravel with specific gravities equal to 2.55 and 2.6, respectively, were used to fabricate the test specimens. The maximum nominal size of the gravel was $20 \mathrm{~mm}$.

\subsubsection{Steel reinforcements}

To define the mechanical properties of the steel bars and plates, tensile tests were conducted on three elements, and the average results are presented in Table (2). 
Table (2): Mechanical properties of the steel bars and plates.

\begin{tabular}{|c|c|c|c|}
\hline Type & $\begin{array}{c}\text { Diameter or } \\
\text { thickness }(\mathrm{mm})\end{array}$ & $\begin{array}{c}\text { Yield strength } \\
\left(\mathrm{N} / \mathrm{mm}^{2}\right)\end{array}$ & $\begin{array}{c}\text { Ultimate strength } \\
\left(\mathrm{N} / \mathrm{mm}^{2}\right)\end{array}$ \\
\hline \multirow{3}{*}{ Bars } & 8 & 457 & 569 \\
\cline { 2 - 4 } & 10 & 547 & 680 \\
\cline { 2 - 4 } & 12 & 553 & 645 \\
\hline \multirow{2}{*}{ Plates } & 1 & 273 & 384 \\
\cline { 2 - 4 } & 1.5 & 295 & 388 \\
\hline
\end{tabular}

\subsubsection{Epoxy resin}

Kemapoxy 165 adhesive mortar has a pre-filled medium viscosity and two solvent-free components of modified epoxy resin with an adequate hardening system. It is an adhesive mortar for steel to concrete.

\subsubsection{Superplasticizer}

Superplasticizer with a specific gravity of 1.15 was used to fabricate the concrete mixes. The superplasticizer, with a high range of water reducer, is a product of $\mathrm{CMB}$ Co. Giza, Egypt.

\subsection{Concrete mixes}

The absolute volume method was applied to design the concrete mixes for the test specimens in groups I and II.

Tap water was used to produce concrete mixes with identical water-to-cement ratios $(\mathrm{w} / \mathrm{c}=0.45)$ but different cement contents. The details of the concrete mixes are presented in Table (3).

Table (3): Concrete Mix Details

\begin{tabular}{|c|c|c|c|c|c|}
\hline $\begin{array}{c}\text { Concrete } \\
\text { Mix. }\end{array}$ & $\begin{array}{c}\text { Cement } \\
\left(\mathrm{kg} / \mathrm{m}^{3}\right)\end{array}$ & $\begin{array}{c}\text { Water } \\
\left(1 / \mathrm{m}^{3}\right)\end{array}$ & $\begin{array}{c}\text { Gravel } \\
\left(\mathrm{Kg} / \mathrm{m}^{3}\right)\end{array}$ & $\begin{array}{c}\text { Sand } \\
\left(\mathrm{Kg} / \mathrm{m}^{3}\right)\end{array}$ & $\begin{array}{c}\text { Super- } \\
\text { plasticizer } \\
\left(1 / \mathrm{m}^{3}\right)\end{array}$ \\
\hline $\begin{array}{c}\text { Mix 1 } \\
\text { (Group I) }\end{array}$ & 400 & 180 & 1185 & 592 & 6 \\
\hline $\begin{array}{c}\text { Mix 2 } \\
\text { (Group II) }\end{array}$ & 500 & 225 & 1050 & 525 & 7.5 \\
\hline
\end{tabular}

\subsection{Fabrication of test specimens}

Four steel plates with different shapes were used to fabricate the steel plate-reinforced concrete composite beams, as presented in Figures (1) and (2). The first shape was the straight steel plates, with a width of 120 $\mathrm{mm}$ and length of $1800 \mathrm{~mm}$. The U-section steel plates had a width of $120 \mathrm{~mm}$, height of $75 \mathrm{~mm}$, and length of $1800 \mathrm{~mm}$. The third type of the steel plate used was the open box (1), with a U-section steel plate connected to the steel plates in the compression zone using five vertical steel wickers on each side. The fourth shape had a steel plate covering the critical shear zone, as presented in Figure (2) panel (d). The shear connectors were fixed to the steel plates; the steel plates and the steel reinforcements were inserted inside of the form work of the beams to be cast. In the case of beam A2, the reinforced concrete beam was cast, and the steel plate was fixed to the soffit of the beam using five anchors and epoxy resin.

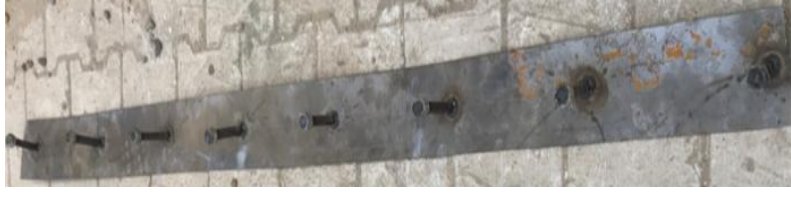

a- Straight steel plate.

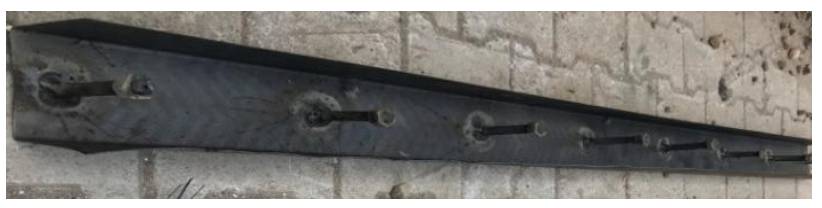

b- U-shaped steel plate.

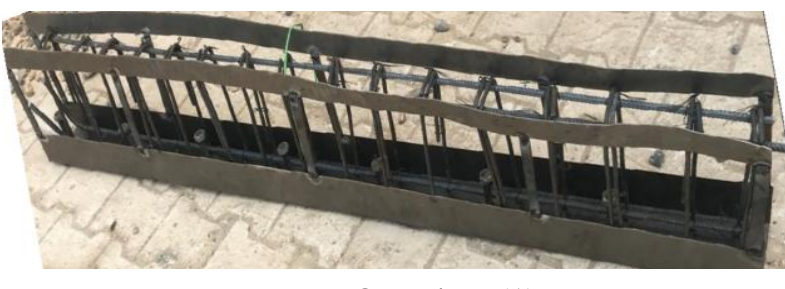

c- Open box (1).

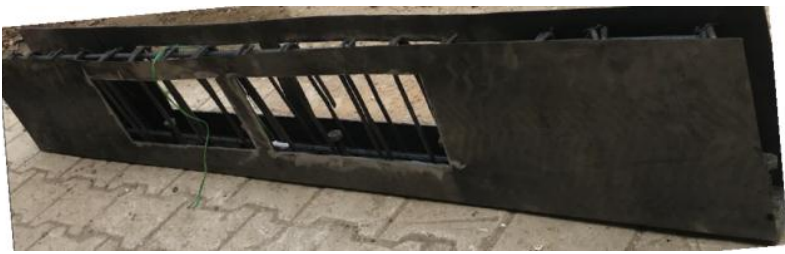

d- Open box (2).

Figure (2): Four different shapes of the steel plates.

\subsection{Instrumentation and testing procedure}

Experimental tests were conducted in the materials laboratory at the Faculty of Engineering at Minia University. After aging for 28 days, the specimens were subjected to a gradually increasing two-point static load using a universal testing machine. The mid-span deflection was measured using linear variable differential transformers, and the strain on the tensile steel reinforcements and steel plates was measured using electrical strain gauges. To determine the width of the flexural cracks, pie gauges were placed at the middle of each test specimen All of the electrical resistance strain gauges, pie gauges, and the displacement transducers were connected to a data logger. The formation and propagations of the cracks were marked and recorded during the loading procedure. 


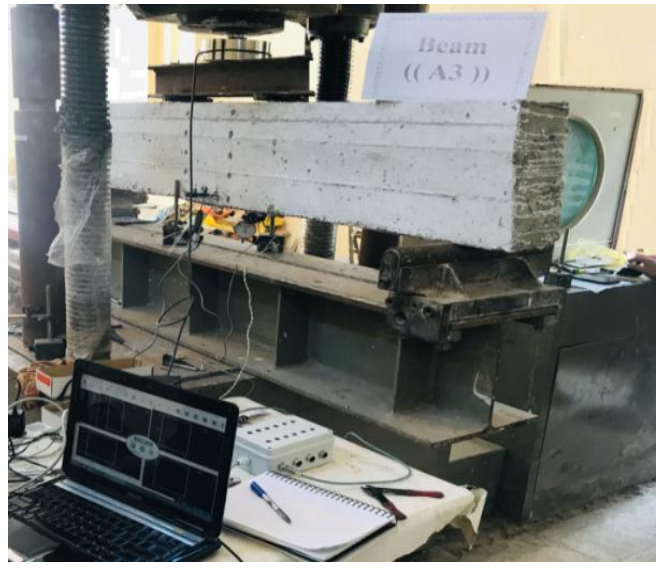

Figure (3): Test setup.

\section{FINITE ELEMENT MODELING}

A nonlinear three-dimensional finite element test using the ANSYS 18.1 program was employed to analyze the steel plate-reinforced concrete composite beams. This finite element study was conducted to verify the experimental test results and to perform an investigation on the additional variables in order to identify the behavior of a low steel reinforcement ratio on steel plate-reinforced concrete beams. The simple support at the left side of the beam has been modeled as a hinge by constraining a single line of load-bearing plate nodes along the width of the beam soffit in the $x$ - and $y$ directions (i.e., $\mathrm{U} x=\mathrm{U} y=0$ ), whereas the other support has been modeled as a roller by constraining the $y$ direction ( $U y=0)$, as presented in Figure (4). The SOLID65 element is used for the 3D modeling of concrete, which is capable of plastic deformation, cracking in three orthogonal directions, and crushing. The SOLID Brick eight-node 185 is used for steel plate modeling. Link180 (steel reinforcement bars) was represented by two nodes, each with three degrees of freedom for translations in the nodal directions. The eight-node interface finite element of CONTACT 174 and TARGE 170 is used for modeling the contact and sliding at the contact surfaces of the concrete and steel plates. The finite element mesh, boundary condition, and loading regions of the steel plate-reinforced concrete composite beams are presented in Figure (4).
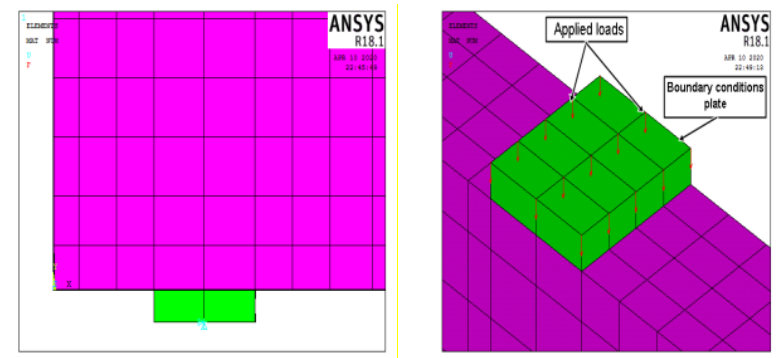

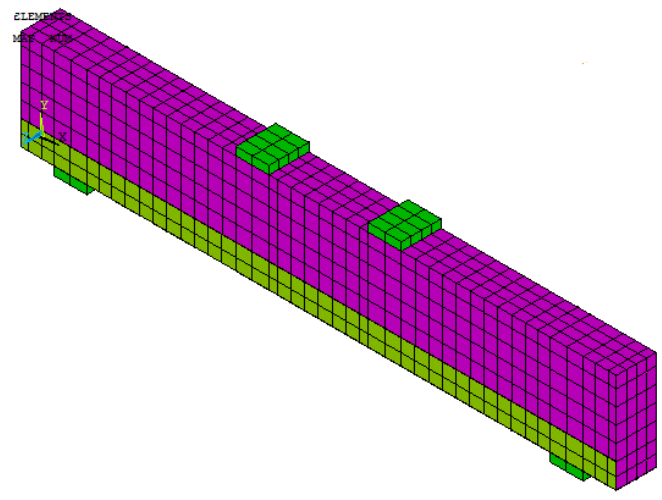

Figure (4): Finite element mesh and boundary conditions.

\section{TEST RESULTS AND DISCUSSION}

\subsection{Patterns of cracks and modes of failure}

Figure (5) presents the patterns of cracks for the 14 test specimens that failed due to flexural stresses. Beams A1 and B1 were conventional reinforced concrete beams that failed due to the formation, propagation, and widening of flexural cracks. A straight steel plate was fixed to the soffit of beam A2 using epoxy resin and five anchors. Upon loading beam A2, flexural cracks formed and propagated. When the load was increased, the cracks widened, and the steel plate and concrete beam were separated halfway between the outer steel anchors. Subsequently, the outer steel anchors were pulled out, and the beam failed. Straight steel plates were fixed to the soffits of beams A3, A4, B2, and B3 using only studs that were fixed before casting. After the formation of the flexural cracks, deformations of the steel plates formed between the shear connectors, reducing the interaction between the steel plates and the concrete sections; this led to the propagation and widening of the flexural cracks. As beams A3, A4, B2, and B3 reached their ultimate loads, the shear connectors were pulled out, and the steel plates were separated from the concrete sections. Beams A5, A6, B4, and B5 were cast over U-shaped steel plates with steel studs. Before the beam failures, loud sounds could be heard which were caused by the slip and separation of the U-shaped steel plates, as presented in Figure (5). Beams A7 and B6 were cast with the open box (1) steel plate. As beams A7 and B6 reached their ultimate loads, buckling of the steel plate in the compression zone and slipping of the U-section in the tension zone occurred, and the flexural cracks widened, leading to the final failure. Steel box (2) exhibited a higher resistance to the formation of the flexural cracks for beam A8. Before failure, the bottom surface of steel box (2) was already deformed, allowing the flexural cracks to extend, which led to the beam's failure. 

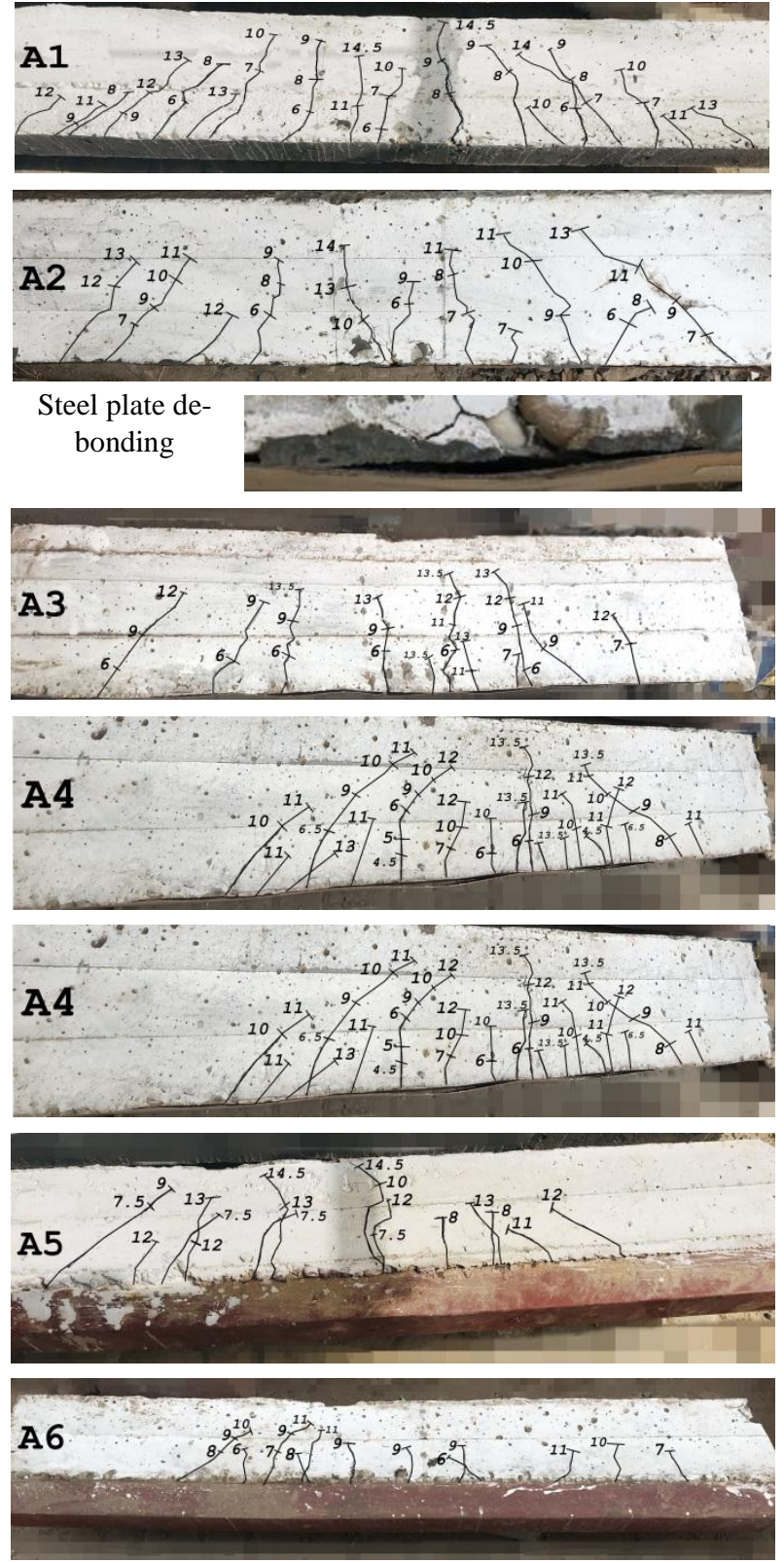

Slip of the steel plate
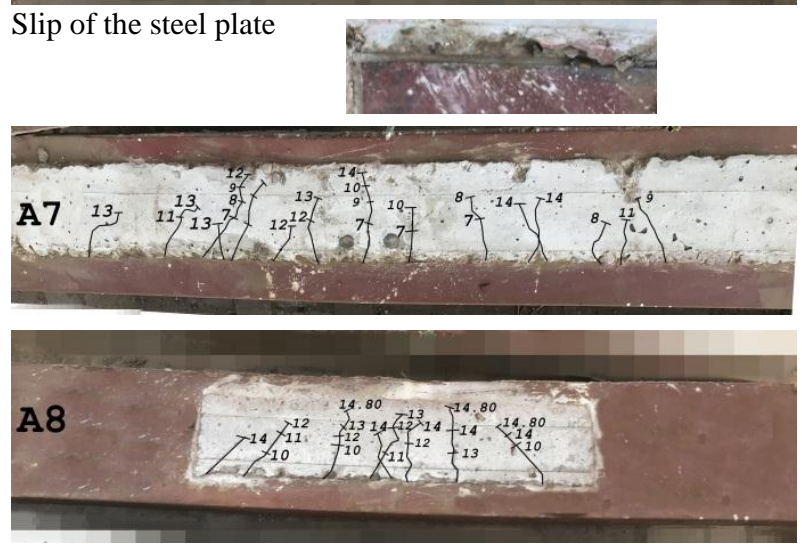

(a): Pattern of cracks for specimens in Group I.

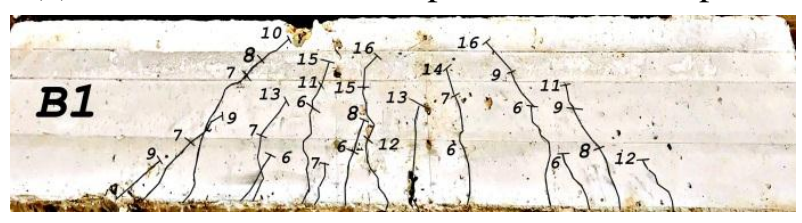

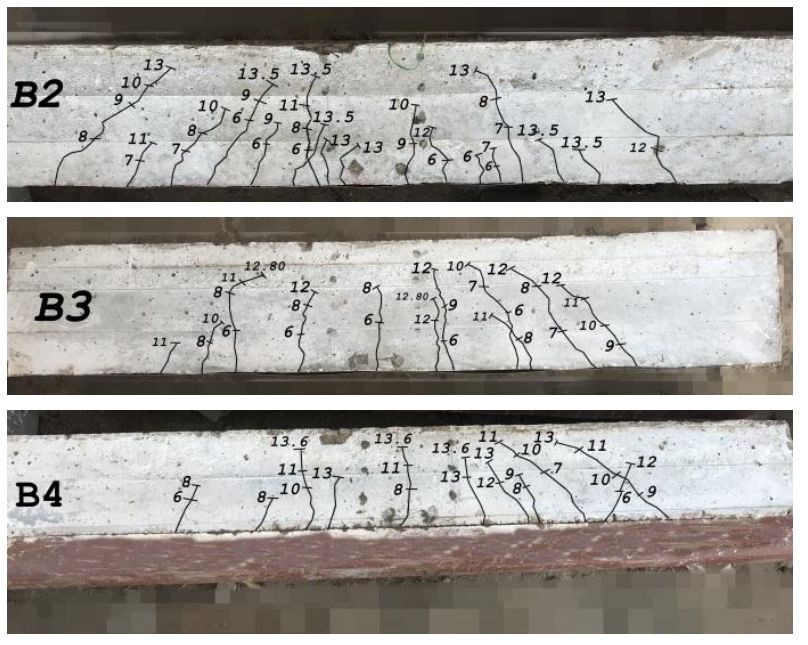
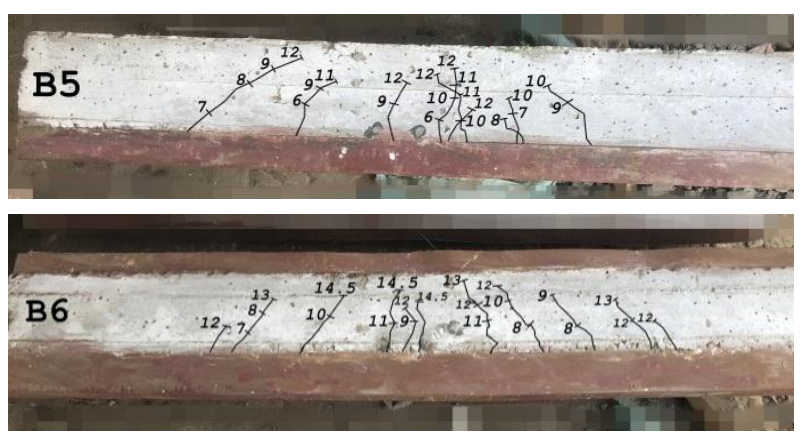

(b): Pattern of cracks for specimens in Group II.

Figure (5): Pattern of cracks.

\subsection{Ultimate loads}

Table (4) and Figure (6) present the ultimate loads of the experimental test specimens in Groups I and II. Beams A1 and B1 were conventional reinforced concrete beams that served as control specimens. The remaining specimens were steel plate-reinforced concrete composite beams. The steel plates were inserted as replacements for the tensile and compressive steel reinforcements in order to maintain a low, but not constant, reinforcement ratio (under the reinforced section). The experimental test results for the specimens in Group I, which had a $30 \mathrm{MPa}$ concrete compressive strength, exhibited up to a $7.6 \%$ reduction in their ultimate loads due to the use of the straight steel plate. This reduction in ultimate loads may be attributed to the use of mild steel plates as replacements for the high-tensile steel reinforcements and the interaction between the steel plates and the concrete. The use of epoxy resin and steel anchors to improve the bond strength between the steel plate and the concrete section of beam A2 resulted in a higher value of ultimate load compared with beams $\mathrm{A} 3$ and A4 [17, 18]. Specimen A5, which had a U-section steel plate thickness of $1 \mathrm{~mm}$ and eight studs, had an equivalent value of the control beam ultimate load. However, the use of a $1.5-\mathrm{mm} \mathrm{U}$-section steel plate and five studs for specimens A6 and B6 resulted in an $\sim 24 \%$ reduction in the ultimate load due to the weak interaction between the steel plate and the concrete beam. Compared with the control specimen, the use of 
a steel plate (open box (1)) resulted in a $3 \%$ reduction in the ultimate load. However, the use of a steel plate for open box (2) exhibited a $2.7 \%$ increase in the ultimate load. Contrary to beams B3 and B4, the increase in the concrete compressive strength of the specimens in Group II slightly improved the ultimate load of the test specimens. The use of the open box (2) steel plate for specimen A8 resulted in the highest value of ultimate load for the specimens in Group I.

\subsection{Deflection and ductility}

Figure (7) presents the load-mid-span deflection curve for the experimental test specimens.
Compared with the control beams, the use of mild straight steel plates as replacements that have almost constant tensile steel reinforcements for beams A2, A3, A4, B4, and B5 resulted in lower values of stiffness at all loading stages. Contrary to the results of previous research [19-21], our values of deflection of the composite beams were higher than those of the control beams. Although the use of epoxy resin with five shear connectors positively increased the value of the ultimate load of beam A2, the values of deflection for beam A2 were lower than those of beams A3 and A4. The use of steel plates which are of U shape and open

Table (4): Experimental and Theoretical Test Results

\begin{tabular}{|c|c|c|c|c|c|c|c|}
\hline Group & Specimen & Exp. U.L.* & Theo. UL- & Exp.U.L./ & Theo. U.L.- & Theo. U.L.HSP & Ductility \\
\hline \multirow{8}{*}{ I } & A1 & 144.3 & 145.1 & 1.01 & 145.1 & 1.00 & 1.5 \\
\hline & $\mathrm{A} 2$ & 139.6 & 153.0 & 1.10 & 162.0 & 1.06 & 1.5 \\
\hline & $\mathrm{A} 3$ & 133.3 & 137.0 & 1.03 & 157.0 & 1.15 & 3.6 \\
\hline & A4 & 134.1 & 141.0 & 1.05 & 155.0 & 1.10 & 2.2 \\
\hline & A5 & 144.0 & 144.0 & 1.00 & 147.5 & 1.02 & 2.2 \\
\hline & A6 & 110.0 & 148.5 & 1.35 & 166.2 & 1.12 & 3.5 \\
\hline & A7 & 140.0 & 143.5 & 1.03 & 168.0 & 1.17 & 2.2 \\
\hline & A8 & 148.2 & 150.0 & 1.01 & 200.0 & 1.33 & 4.2 \\
\hline \multirow{6}{*}{ II } & $\mathrm{B} 1$ & 160.0 & 160.5 & 1.00 & -- & - & 1.6 \\
\hline & B2 & 134.1 & 142.5 & 1.06 & -- & -- & 1.8 \\
\hline & B3 & 128.1 & 142.1 & 1.11 & -- & -- & 1.6 \\
\hline & B4 & 136.6 & 147.5 & 1.08 & -- & -- & 1.9 \\
\hline & B5 & 121.9 & 154.5 & 1.27 & -- & -- & 2.8 \\
\hline & B6 & 145.0 & 145.5 & 1.00 & -- & -- & 2.8 \\
\hline
\end{tabular}

*Experimental values of ultimate loads. **Theoretical values of ultimate loads (using mild steel plate) *** Theoretical values of ultimate loads (using high-tensile steel plate)

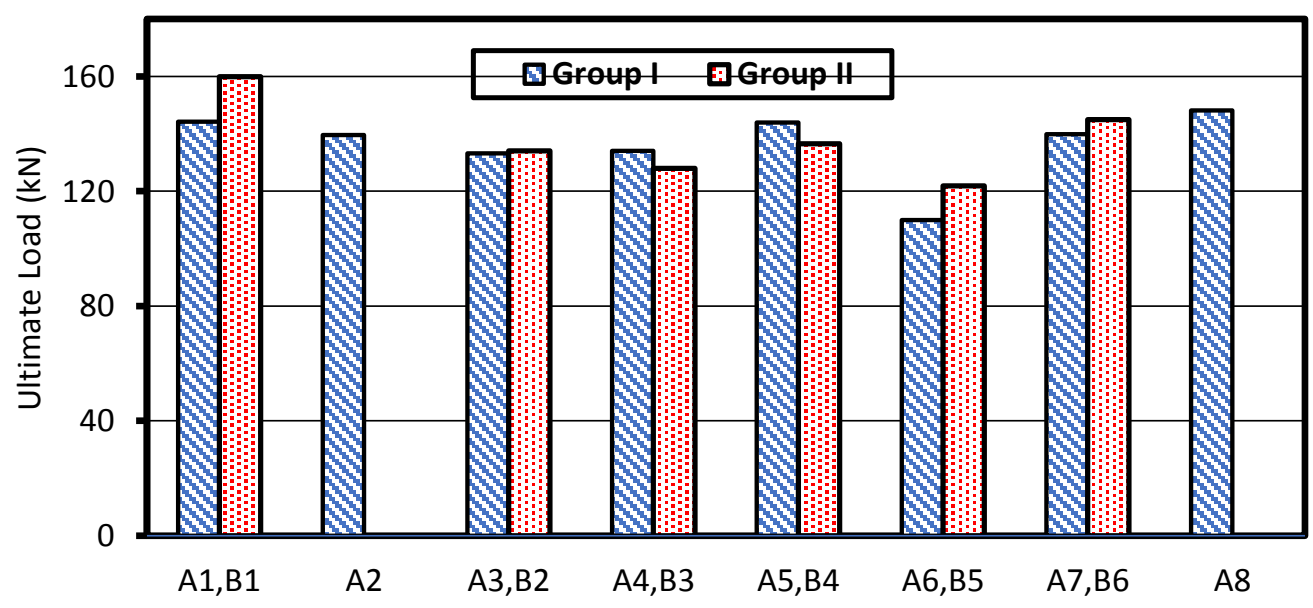

Figure (6): Experimental values of the ultimate loads for the test specimens.

box (1) shape for the composite beams exhibited stiffness that is almost equal to that of control beams at the first stage of loading. Upon increasing the load, the slip between the steel plates and the concrete sections resulted in lower values of stiffness and higher values of deflection of the composite beams. However, the use of the open box (2) steel plate revealed the highest value of stiffness due to 
the improved interaction between the steel plates and the concrete beams; see Figure (7).

The ductility of the experimental test specimens was measured as a ratio of the deflections at failure to the deflection at the yield loads. Generally, the composite beams showed higher values of ductility than the conventional reinforced concrete beams [22-23]. The use of the steel plate (open box (2) shape) for beam A8 resulted in the highest value of ductility, which was $280 \%$ higher than the ductility of the control beam. The use of eight studs to fix the

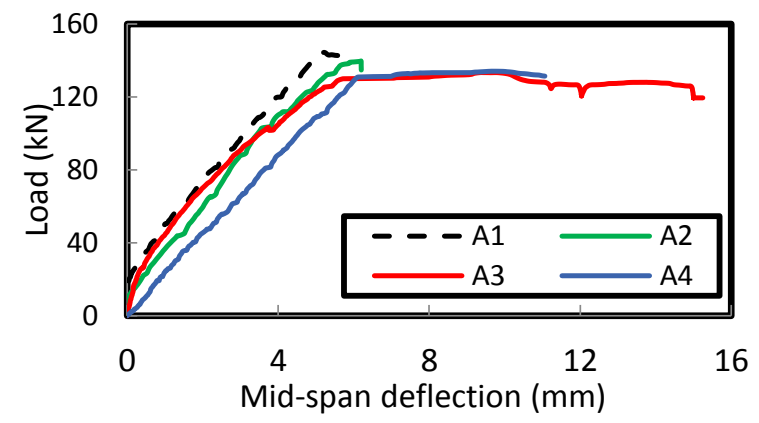

a- Effect of the straight steel plate.

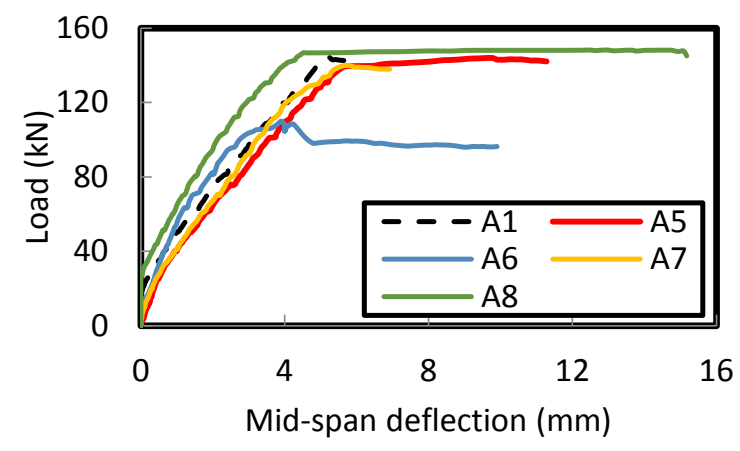

b- Effect of the steel plate shape.

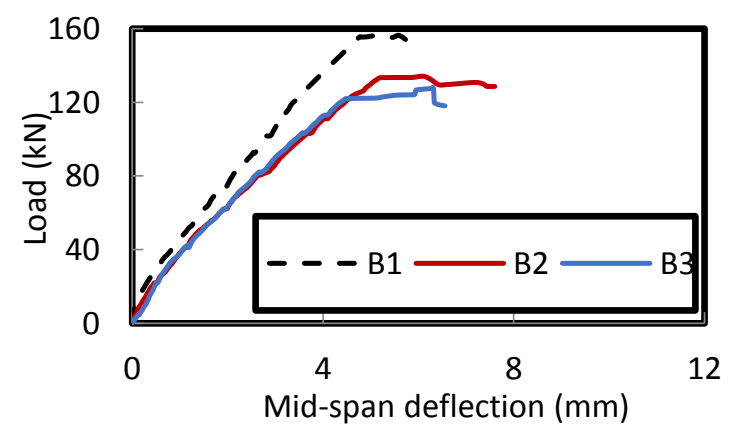

c- Effect of the straight steel plate. steel plate to the soffit of the RC beams for specimens A3 and B2 exhibited higher values of ductility than for specimens A4 and B3, which only had five studs. Although specimen A2 exhibited a high load-bearing capacity, the use of epoxy resin and five shear connectors to fix the steel plate resulted in the lowest value of ductility. The ductility of the composite beams was affected by the interaction between the steel plate and the concrete beams, as presented in Table (4).

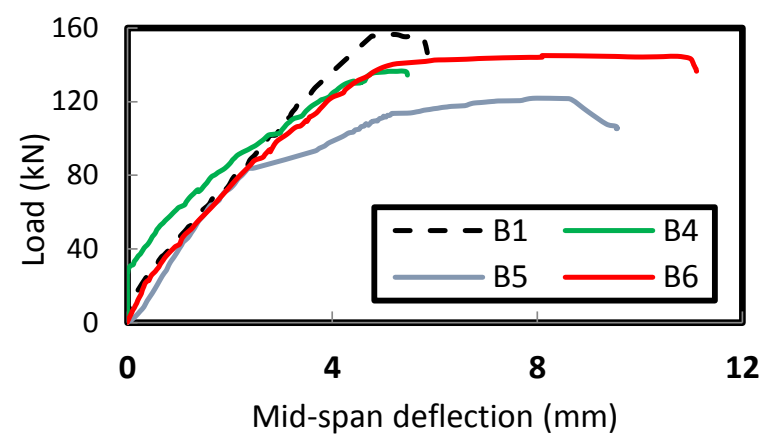

d- Effect of the steel plate shape.

Figure (7): Load-deflection for the test specimens.

\subsection{Strain in steel plates and tensile steel bars}

Reaching the yield strain of the steel plate indicates a high efficiency of the steel plate-reinforced concrete composite beams. Using five shear connectors to fix the U-section steel plate $(1.5 \mathrm{~mm}$ thickness) resulted in low values of strain in the steel plate for beams A6 and B5; see Figure (8). The ultimate loads of these beams were about $24 \%$ lower than those of the control beams. The values of strain in the steel plates of the remaining composite beams were higher than those of the yield strain, indicating an acceptable level of steel plate and concrete section interaction. Figure (9) presents the strain in the tensile steel bars of the beams in Group I. Except for beam A2, the tensile steel bars reached the yield point. The de-bonding of the steel plate resulted in the lowest value of strain in the tensile reinforcement of beam A2. 

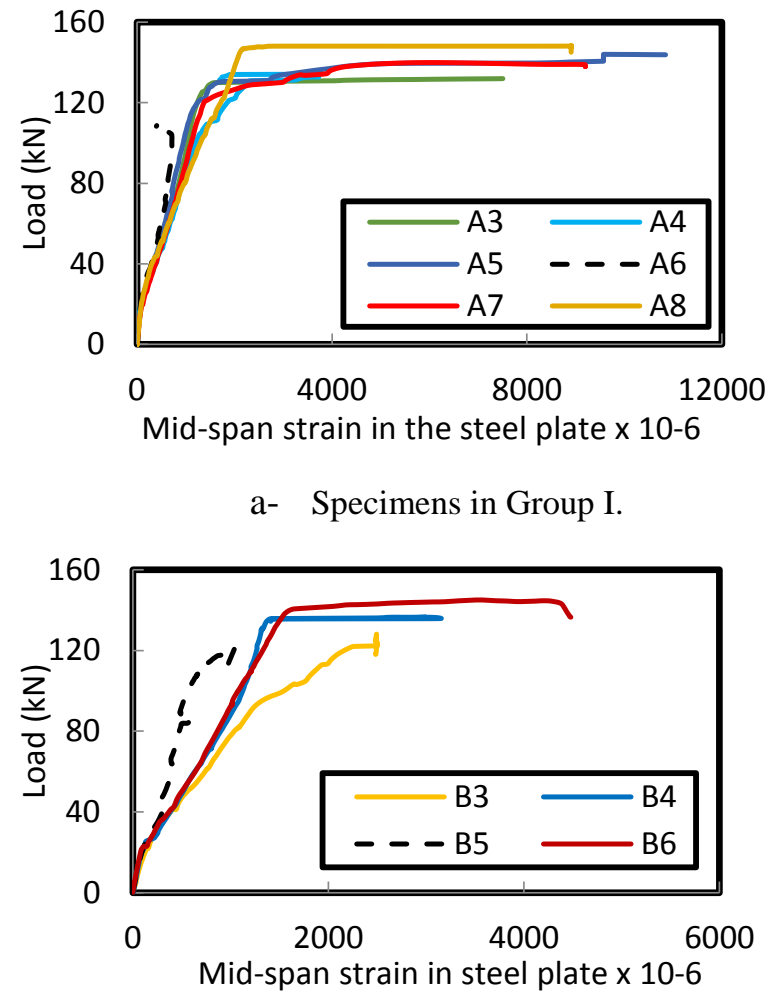

b- Specimens in Group II.

Figure (8): Load-strain relationship of the steel plates.

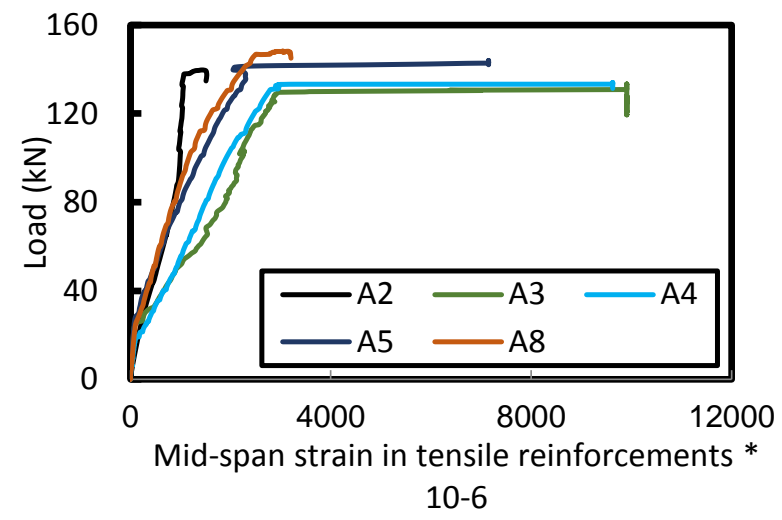

Figure (9): Load-strain relationship of the tensile steel

\subsection{Crack width}

bars.

The mid-span crack widths of the control beams and composite beams with straight steel plates were measured at a depth of $275 \mathrm{~mm}$. The midspan crack width of the remaining composite beams was measured at a depth of $200 \mathrm{~mm}$. The maximum crack width of the control beam (A1) at the mid-span was $0.75 \mathrm{~mm}$. Using five shear connectors and epoxy resin or using eight studs to fix the steel plates of beams A2 and A3 resulted in similar values of mid-span crack widths to those of the control beam. However, the use of only five studs to fix the steel plate of beam B4 resulted in a $1.9-\mathrm{mm}$ maximum crack width, which is $240 \%$ higher than that of the control beam A1; see
Figure (10) panel (a). The use of open box (2) steel plate for beam A8 resulted in the lowest value of maximum crack width at the mid-span compared with those of beams A5 and A6, which have U-shaped steel plates, as presented in Figure (10) panel (b).

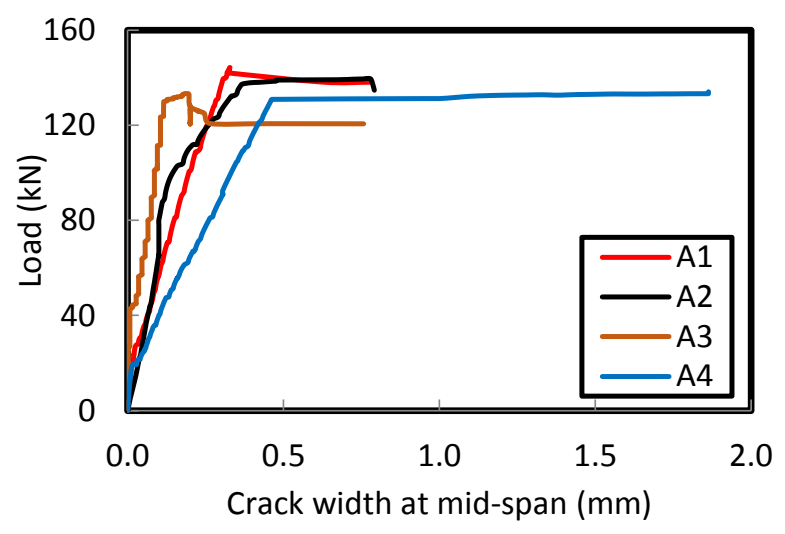

a- Mid-span crack width at a depth of $275 \mathrm{~mm}$.

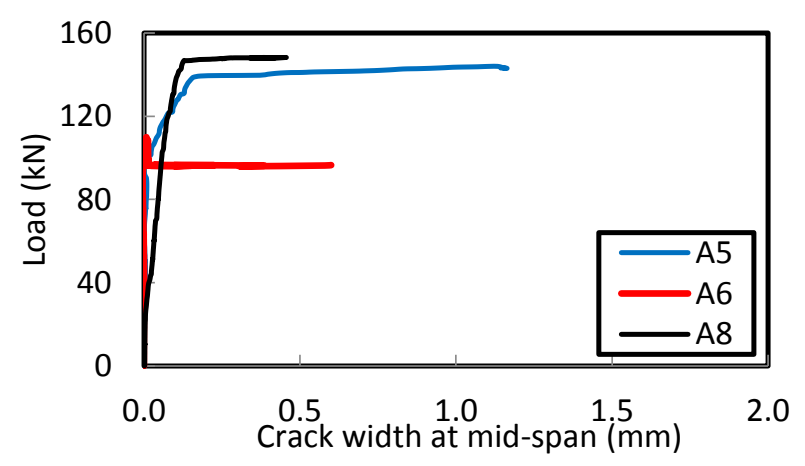

b- Mid-span crack width at a depth of $200 \mathrm{~mm}$.

Figure (10): Mid-span crack width.

\section{THEORETICAL RESULTS}

The experimental and theoretical values of the ultimate loads of the steel plate-reinforced

concrete composite beams are presented in Table (4). Except for beams A6 and B5, the ultimate load capacities of the test specimens could be reasonably predicted using the simulation software. The experimental and theoretical values of the ultimate loads deviated in the range of 0.0 $\%-11 \%$. Because mild steel plates were used as replacements for the high-tensile steel reinforcements, the experimental test results did not exhibit a clear improvement in the loadbearing capacity of the steel plate-reinforced concrete composite beams. Hence, the theoretical study investigates the effect of the values of the steel plates' yield strength and the use of the steel 
plate as an additional steel reinforcement for the reinforced concrete beams.

Figure (11) and Table (4) present the effect of the yield strength of the steel plates on the predicted values of the ultimate loads. Generally, the predicted values of the ultimate loads for all composite beams (fabricated using high-tensile steel plates) were higher than that of the ultimate load of the control beam. The use of high-tensile steel plates (yield strength $=553 \mathrm{~N} \mathrm{~mm}^{-2}$ ) increased the predicted values of the ultimate loads for the composite beams by about $15 \%$, $12 \%$, and $33 \%$ for the straight steel plate, Ushaped steel plate, and open box (2) steel plate, respectively.

To investigate the improvement in the flexural strength of the composite beams with steel plates as additional steel reinforcement, the theoretical study includes seven beams, A1' to A7 . These beams have the same stirrup details, shear connectors, concrete strengths, and concrete dimensions $(120 \times 300 \times 1600 \mathrm{~mm})$ as the those of the experimental test specimens (A1 to A7). The tensile and compressive steel reinforcements are 2016 and 2012 , respectively. Except when using high-tensile steel plates, beams A2 to A7 have the same thicknesses and shapes of the steel plates used for beams A2 to A7, respectively. As presented in Figure (12), the values of the ultimate loads of the composite beams were found to increase as a result of the increase in the tensile steel reinforcement ratio. Compared with the control beam A1 ', the use of a straight steel plate, U-shaped steel plate, and open box (1) steel plate resulted in $22.5 \%, 30.2 \%$, and $42.3 \%$ increases in the values of the ultimate loads, respectively.

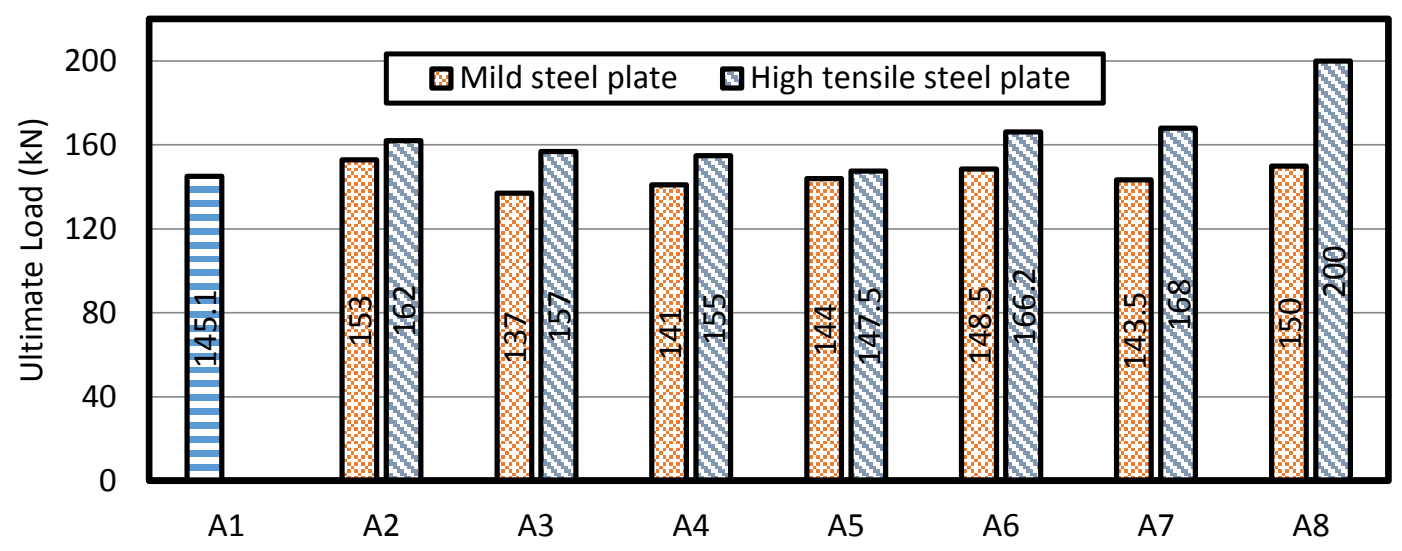

Figure (11): Effect of the steel plate yield strength on the values of the ultimate loads.

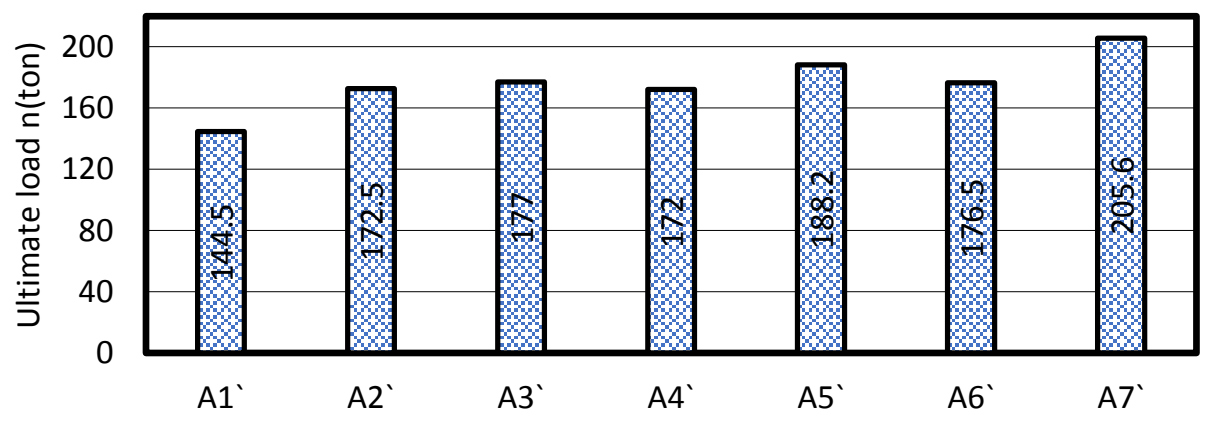

Figure (12): Predicted values of the ultimate loads.

\section{CONCLUSIONS}

From the experimental and theoretical investigations conducted in this study, the following conclusions were drawn:

1- To increase the load-bearing capacity and efficiency of the composite beams, the bond strength between the steel plates and the reinforced concrete beams should be increased by using epoxy adhesive and a sufficient number of mechanical anchors.

2- In using mild steel plates as replacements for the high-tensile steel reinforcements, the experimental test results did not exhibit a clear improvement in the load-bearing capacity of the steel platereinforced concrete composite beams. 
3- The experimental test results revealed that the ductility of the composite beams could be up to $280 \%$ higher than that of conventional reinforced concrete beams. The ductility of the composite beams was affected by the interaction of the steel plate and the reinforced concrete beams.

4- The nonlinear finite element analysis revealed that the use of high-tensile steel plate as replacements for the steel reinforcements increases the predicted values of the ultimate loads for the composite beams by about $15 \%, 12 \%$, and $33 \%$ for the straight steel plate, U-shaped steel plate, and open box (2) steel plate, respectively.

5- To investigate the improvement in flexural strength of the composite beams with steel plates as additional steel reinforcement, the numerical study revealed that the use of straight steel plates, Ushaped steel plates, and open box (1) steel plates resulted in $22.5 \%, 30.2 \%$, and $42.3 \%$ increases in the ultimate loads, respectively. The ultimate loads of the composite beams were found to increase with the increase in the tensile steel reinforcement ratio.

\section{REFERENCES}

1) N. Vinay, M.L. Harish, R. Prabhakara "Experimental Investigation on the Flexural Behavior of the SteelConcrete Composite Beams" International Research Journal of Engineering and Technology (IRJET), Vol. 2, No. 7, Oct, 2015, pp. 1293-1301.

2) Qiao Huang Bing Wang Li "Experimental Investigation of Steel-Concrete Composite Beams with Different Degrees of Shear Connection under Monotonic and Fatigue Loads" Advances in Structural Engineering Journal Xiaoling Liu andWenxian, and Wenxian, Vol. 21, No. 2, 2018, pp. 227-240.

3) Pooja Podar, Gargi Rajpara "Experimental Behavior of Composite Beam Using Hot Rolled Channel and Cold Formed Lipped Channel Section under Flexure" international Journal of Innovative Technology and Exploring Engineering (IJITEE), Vol. 9, No. 5, March, 2020, pp. 2278-3075.

4) Jun Deng, Marcus M.K. Lee, Shiqing Li "Flexural Strength of Steel-Concrete Composite Beams Reinforced with a Prestressed CFRP Plate" Construction and Building Materials, Vol. 25, No. 1, 2011, pp. 379-384.

5) Kapil Grover, Gupta Sakshi "Flexural Capacity of Composite Beams (Steel \& Concrete) - A Review" IOSR Journal of Mechanical and Civil Engineering, Special Issue - AETM'16, Vol. 01, No. 1, 2016, pp. 66-72.

6) Laith Khalid Al-Hadithy, Omer Khalid Al-Kerbooli "Experimental and Finite Element Investigation of Composite Beams Consisting of Reinforced Concrete Prisms Cast into Steel Channels" $1^{\text {st }}$ Regional Conference of Engineers Science NUCEJ Spatial ISSUE Vol. 11, No. 1, 2008 pp 1-18.
7) Panuwat Joyklad, Suparp Suparp "Experimental Response of Jacketed RC Beams" International Journal of Structural and Civil Engineering Research, Vol. 6, No. 4, November, 2017, pp. 245251.

8) Rafid Saeed Atea "A Case Study of Flexural Performance of Reinforced Concrete Beams Bonded with Steel Plates with Different Thickness" Journal of Materials Research and Technology, Vol. 8, No. 1, 2019, pp. 22-32.

9) Ștefan-Marius BURU “Advanced Analysis of SteelConcrete Composite Structures" PhysiologyD. Thesis Technical University of CLUJ-NAPOCA Faculty of Civil Engineering, 2016.

10) R. Mark Lawson, Dennis Lam, Eleftherios S. Aggelopoulos, Sebastian Nellinger "Serviceability performance of steel-concrete composite beams" Proceedings of the Institution of Civil Engineers Structures and Buildings, Volume 170 Issue SB2, February 2017, PP. 98-114.

11) Pengzhen Lu, Changyu Shao "A new model for composite beams with partial interaction" Proceedings of the Institution of Civil Engineers - Engineering and Computational Mechanics, Volume 167 Issue 1, March 2014, pp. 30-40.

12) M. A. Bradford, R. I. Gilbert "Time-dependent behaviour of simply-supported steel-concrete composite beams" Magazine of Concrete Research, Volume 43 Issue 157, December 1991, pp. 265-274.

13) Changyong Liu, Yuyin Wang, Tak-Ming Chan, Qinghe Wang "Flexural and shear capacities of semi-precast RC beams with embedded steel connections" Magazine of Concrete Research, Volume 71, Issue16, julue 2019, pp. 827-846.

14) $\mathrm{P}$ Ansourian "Experiments on Continuous Composite Beams" Proceedings of the Institution of Civil Engineers, Volume 73 Issue 1, MARCH 1982, pp. 26-51.

15) Nasser H. Tu'ma, M.R. Aziz "Flexural Performance of Composite Ultra-High-Performance ConcreteEncased Steel Hollow Beams" Civil Engineering Journal, Vol. 5, No. 6, June, 2019, 1289-1304.

16) Mohammad M. El Basha, Tarek K. Hassan, A. Omar El-Nawawy "Efficiency of Hollow Reinforced Concrete Encased Steel Tube Composite Beams" International Journal of Civil Engineering and Technology (IJCIET), Vol. 9, No. 3, 2018, pp. 720-735.

17) Sandile D. Ngidi, Morgan Dundu "Composite Action of Pre-Cracked Reinforced Concrete Beams Repaired with Adhesive Bonded Steel Plates" Structures, Vol. 14, 2018, pp. 400-408.

18) Shatha Alasadi, Zainah Ibrahim, Payam Shafigh, Ahad Javanmardi, Karim Nouri "An Experimental and Numerical Study on the Flexural Performance of Over-Reinforced Concrete Beam Strengthening with Bolted-Compression Steel Plates: Part II" Applied Sciences, Vol. 10, No. 1, 2020, p. 94. 


\section{Vol. 41, No.2. July 2022}

19) L.Z. Li, S.H. Lo, R.K.L. Su "Experimental Study of Moderately Reinforced Concrete Beams Strengthened with Bolted-Side Steel Plates" Advances in Structural Engineering, Vol. 16, No. 3, 2013, pp. 499-516.

20) Rendy Thamrin, R.P. Sari "Flexural Capacity of Strengthened Reinforced Concrete Beams with Web Bonded Steel Plates" Procedia Engineering, Vol. 171, 2017, pp. 1129-1136.

21) Marcin Górecki, Krzysztof Sledziewski 'Experimental Investigation of Impact Concrete Slab on the Bending Behavior of Composite Bridge Girders with Sinusoidal Steel Web' Materials. Journal, Vol. 13, No. 2, 273, 2020, pp. 1-14.

22) Ahmed Hassan, Faisal Aldhafairi, L.M. Abd-ElHafez, A.E.Y. Abouelezz "Retrofitting of Different Types of Reinforced Concrete Beams after Exposed to Elevated Temperature" Engineering Structures, Vol. 194, 2019, pp. 420-430.
23) S. Thondel, J. Studnicka "Behaviour of SteelConcrete Composite Beam with High Ribbed Deck" Procedia Engineering, Vol. 40, 2012, pp. 457-462.

24) Yuntian Wu, Daoyang Kang, Long Gao, Yiting Su, Yang Yang "Seismic Behavior of Bolted Endplate Connection between Steel Reinforced Concrete (SRC) Wall and SRC Beam for Use in High-Rise Buildings" International Journal of Civil Engineering, Vol. 16, No. 11, 2018, pp. 1561-1572.

25) Paweł Szeptyński "Comparison and Experimental Verification of Simplified One-Dimensional Linear Elastic Models of Multilayer Sandwich Beams" Composite Structures, Vol. 241, 2020, pp. 1-13. 
خصائص الكمرات الخرسانية المسلحة المركبة المصبوبة داخل قطاعات من الحديد والمعرضة لاجهادات انحناء

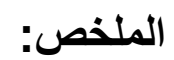

تُشتخدم العناصر المصبوبة داخل قطاعات من الحديد لأنواع خاصة من المنشآت نظراً لكفاءتها العالية. يقدم هذا

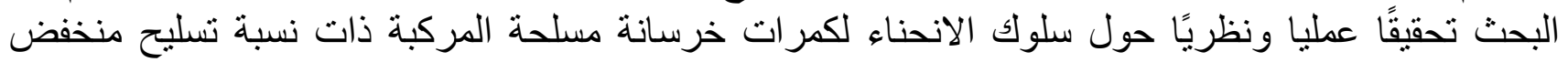

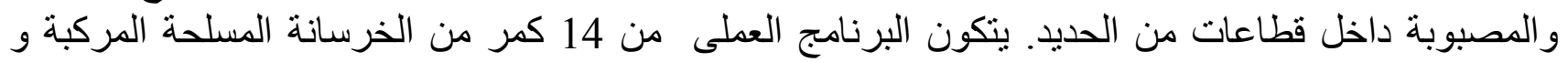

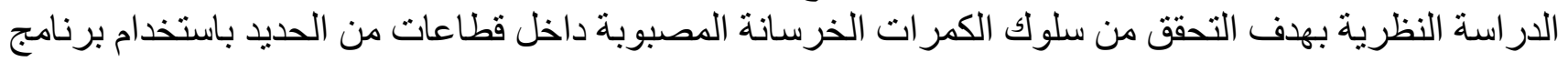

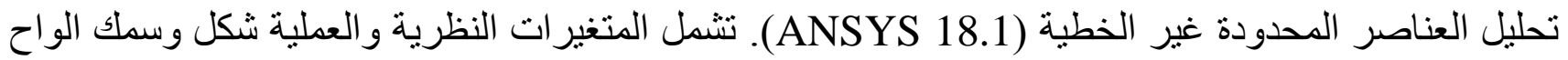

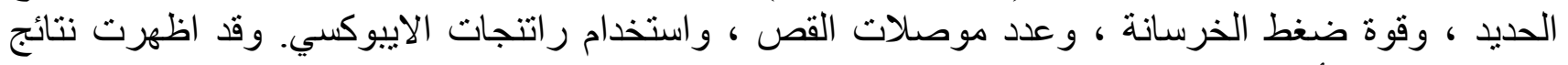

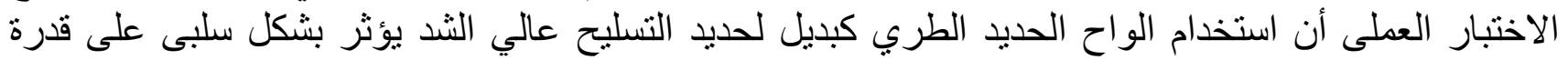

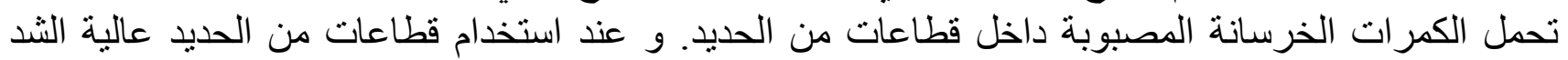
كتعزيزات إضافية ، توقع برنامج تحليل العناصر المحدودة غير الخطية زيادة تصل الخدل إلى 40٪ في قدرة تحمل الكمر ات الخرسانية. 